\title{
The Influence of Surface Charge on the Attachment of Neisseria gonorrhoeae to Human Cells
}

\author{
By J. E. HECKELS, B. BLACKETT, J. SYLVIA EVERSON AND \\ M. E. WARD \\ Microbiology - Faculty of Medicine, Southampton General Hospital, \\ Southampton $\mathrm{SO}_{9} 4 \mathrm{XY}$
}

(Received 5 March 1976; revised 24 May 1976)

\begin{abstract}
SUMMARY
Isoelectric focusing showed that Neisseria gonorrhoeae has an overall negative surface charge. Chemical modification of protein amino or carboxyl groups changed the surface charge and thereby altered the ability of the organisms to attach to human amnion cells grown in tissue culture. Attachment of modified and unmodified $N$. gonorrhoeae was increased by the presence of pili only when the bacteria bore a negative surface charge. Thus an important factor in the pathogenesis of gonorrhoea may be the ability of pili to facilitate attachment of $N$. gonorrhoeae by overcoming the initial electrostatic repulsive barrier which exists between it and the host cell.
\end{abstract}

\section{INTRODUCTION}

The ability of many pathogenic micro-organisms to attach to a particular surface of their host is fundamental to their ability to colonize and invade that host. Thus the ability of Neisseria gonorrhoeae to attach to mucosal surfaces and to multiply there, despite the flow of urine and mucus secretions, is of crucial importance in the pathogenesis of gonorrhoea (Ward \& Watt, 1972). Little is known of the molecular forces involved in such attachment although the presence of pili on the organism is probably an important factor. Pili facilitate the attachment of the bacteria, in vitro, to each other (Swanson, Kraus \& Gotschlich, I97I), to human cells in tissue culture (Swanson, I973) and to human sperm (James-Holmquest et al., 1974), all of which may be related to the establishment and spread of the natural infection. In addition the loss of pili is associated with decreased virulence in human volunteers (Kellogg et al., I963).

The initial interaction between $N$. gonorrhoeae and the host cell is likely to be dominated by electrostatic forces as these operate over relatively long distances (Curtiss, 1973). Investigations using electrophoresis (Gittens \& James, 1963) and isoelectric focusing (Sherbet \& Lakshmi, 1973) have shown that in Gram-negative bacteria the major contribution to surface charge is made by amino and carboxyl groups exposed at the surface, and that these bacteria, like mammalian cells, have an overall net negative surface charge. If $N$. gonorrhoeae also has a negative surface charge then there will be an electrostatic repulsive force between it and the mucosal surface which must be overcome before attachment can occur. Thus the advantage which pili confer in attachment might be related to an ability to overcome this initial electrostatic barrier.

To investigate the influence of surface charge and degree of pilation on the attachment of $N$. gonorrhoeae to human cells grown in tissue culture, we have used bacteria whose surface charge has been modified by selectively blocking charged groups in the bacterial proteins. 


\section{METHODS}

Growth and harvesting. Neisseria gonorrhoeae strains $\mathrm{F} 62$ and P9, colony types I (pilated) and 4 (non-pilated), were used. Bacteria were grown overnight on Bacto GC medium base (Difco) supplemented as described by White \& Kellogg (I965). Organisms from five plates were suspended in Io $\mathrm{ml} \mathrm{I} \%(\mathrm{w} / \mathrm{v})$ proteose peptone no. 3 broth (Difco) and used to inoculate a liquid culture $(200 \mathrm{ml}$ ) containing (per litre): proteose peptone, $15 \mathrm{~g} ; \mathrm{NaCl}, 5 \mathrm{~g}$; $\mathrm{K}_{2} \mathrm{HPO}_{4}, 3 \mathrm{~g} ; \mathrm{Na}_{2} \mathrm{HPO}_{4} .2 \mathrm{H}_{2} \mathrm{O}$, I g; glucose, $4 \mathrm{~g}$; DL-glutamine, o. I g; $\mathrm{Fe}\left(\mathrm{NO}_{3}\right)_{3}$, Io mg; thiamine pyrophosphate, $0.2 \mathrm{mg}$. Bacteria were grown with shaking at $37^{\circ} \mathrm{C}$ for $4 \mathrm{~h}$, harvested by centrifuging at $8000 \mathrm{~g}$ for Io min and washed twice with phosphate-buffered saline $\mathrm{pH} \mathrm{7.3} \mathrm{(PBS)} \mathrm{before} \mathrm{use.}$

Modification of amino groups. Amino groups were blocked by reaction with formaldehyde according to the method of Sherbet \& Lakshmi (1973). The modified bacteria were recovered by centrifuging, washed with PBS and stored in liquid nitrogen until required. The extinction of the mixture at $600 \mathrm{~nm}$ remained essentially constant during the reaction and no material which absorbed at $260 \mathrm{~nm}$ was released into the supernatant solution.

Modification of carboxyl groups. Carboxyl groups were blocked using a modification of the method of Hoare \& Koshland (1967). A solution (5.0 ml) containing I-ethyl-3-(dimethylaminopropyl)carbodiimide (EDC; Sigma; $0.5 \mathrm{~g}$ ), methylamine hydrochloride $(0.6 \mathrm{~g})$ and $\mathrm{MgCl}_{2} \cdot \mathrm{H}_{2} \mathrm{O}(5 \cdot 0 \mathrm{mg})$ was adjusted to $\mathrm{pH} 4 \cdot 5$ with I $\mathrm{M}-\mathrm{HCl}$, and to this was added a suspension $(5 \mathrm{ml})$ of bacteria in $0.8 \%(\mathrm{w} / \mathrm{v}) \mathrm{NaCl}$ solution to give a final $E_{600}$ of approximately I. The reaction mixture was stirred at $25^{\circ} \mathrm{C}$ and at intervals the $\mathrm{pH}$ was readjusted to 4.5 by adding $\mathrm{O} \cdot \mathrm{I} \mathrm{M}-\mathrm{NaOH}$. After $4 \mathrm{~h}$, no further additions of base were necessary, and after allowing the mixture to stand for a further $\mathrm{I} 6 \mathrm{~h}$, bacteria were recovered by centrifuging, washed with PBS and stored in liquid nitrogen. The extinction of the reaction mixture at $600 \mathrm{~nm}$ did not decrease during the course of the reaction.

In some experiments bacteria which had previously been treated with formaldehyde were subjected to the above procedure to produce bacteria in which both amino and carboxyl groups were blocked.

Isoelectric focusing of bacteria. Bacteria were focused in an LKB (Bromma, Sweden) 8100 column using an adaptation of the post-pH equilibrium method of Sherbet \& Lakshmi (1973) which avoided the need for modifying the column and allowed each $\mathrm{pH}$ gradient to be used up to three times. Before filling the column, a narrow Teflon tube connected to a peristaltic pump was inserted into the column via the filling nipple so that the end of the tube was near to the position of the anticipated final $\mathrm{pH}$ value. The supporting gradient used was 60 to $10 \%$ glycerol containing I \% (w/v) ampholine, a polyamino-polycarboxylic acid (LKB), of a suitable narrow $\mathrm{pH}$ range; and the current was applied for $36 \mathrm{~h}$ to establish the $\mathrm{pH}$ gradient. A sample ( $\mathrm{I} \mathrm{ml}$ ) of the gradient was then removed via the pump and modified or unmodified bacteria were mixed with it to give an $E_{600}$ of approximately 2. The sample was returned to the column and the current was applied until the band of bacteria had ceased to migrate (I to $2 \mathrm{~h}$ ). The position of the Teflon tube was readjusted so that a sample of the gradient at the final point attained could be removed and the $\mathrm{pH}$ was measured. Using this method, the sample could be returned to the column, the $\mathrm{pH}$ gradient refocused and a second or third sample applied, since the original bacteria precipitated at their pI and slowly fell to the bottom of the column.

Tissue culture. WISH human amnion cells (Flow Laboratories, Irvine, Ayrshire) were grown in Eagle's basal medium plus Earle's balanced salt solution buffered with $\mathrm{NaHCO}_{3}$ and containing $15 \%$ (v/v) foetal calf serum (all from Flow Laboratories). Cells were 
suspended in tissue culture medium ( $\mathrm{I} \mathrm{ml}$ ) to give $3 \times 10^{4}$ cells $/ \mathrm{ml}$ and were grown for $20 \mathrm{~h}$ at $37^{\circ} \mathrm{C}$ on $13 \mathrm{~mm}$ diam. coverslips placed on the bottom of a $5 \mathrm{ml}$ plastic Bijou bottle, in an atmosphere containing $5 \%(\mathrm{v} / \mathrm{v}) \mathrm{CO}_{2}$. The medium was then removed and replaced with 2-( $N$-2-hydroxyethylpiperazin- $N^{\prime}$-yl)ethanesulphonic acid (HEPES)-buffered medium (Flow Laboratories; $0.5 \mathrm{ml}$ ) without serum.

Attachment of $N$. gonorrhoeae to tissue culture cells. Modified or unmodified $N$. gonorrhoeae were suspended in HEPES-buffered tissue culture medium and centrifuged at $150 \mathrm{~g}$ for $8 \mathrm{~min}$ to remove any large aggregates of bacteria. The upper two-thirds of the suspension was removed; phase-contrast microscopy indicated that it was largely unaggregated diplococci. A sample of this suspension was diluted in tissue culture medium to give $2.5 \times 10^{6}$ diplococci/ml, as determined by Coulter counting, and $0.5 \mathrm{ml}$ was added to each bottle containing WISH cells.

Neisseria gonorrhoeae were deposited on the cells by centrifuging at $600 \mathrm{~g}$ for $5 \mathrm{~min}$, incubated at $37^{\circ} \mathrm{C}$ for $\mathrm{I} .5 \mathrm{~h}$, the medium was removed and the coverslips were gently washed $(2 \times 5 \mathrm{ml})$ with Dulbecco AB buffer (Oxoid). Cells were fixed in methanol, stained with I \% crystal violet for $10 \mathrm{~s}$, rinsed with distilled water and dried. The coverslips were treated with xylene and mounted on glass slides. The cells were examined under a light microscope with an oil immersion lens and the mean number of $N$. gonorrhoeae attached per cell was determined by counting the number of bacteria associated with at least 50 cells.

Electron microscopy with cationized ferritin. Unfixed or chemically modified $N$. gonorrhoeae $\mathbf{P 9}$ were suspended in I $\mathrm{ml}$ PBS and $0.2 \mathrm{ml}$ of a solution of cationized ferritin (MilesYeda, Rehovoth, Israel), containing approximately $\mathrm{I} \mathrm{mg}$ protein, was added. After $5 \mathrm{~min}$ at room temperature, the bacteria were washed three times in PBS, fixed in $2.5 \%(\mathrm{w} / \mathrm{v})$ purified glutaraldehyde (Taab Laboratories, Reading, Berkshire) in O. I M cacodylate buffer $\mathrm{pH} 7.3$, postfixed with I \% (w/v) Palade-buffered osmium tetroxide solution followed by $\mathrm{I} \%$ (w/v) aqueous uranyl acetate, and embedded in low viscosity Spurr's resin (Taab Laboratories). Ultra-thin sections were cut with a diamond knife and examined with a Philips EM 300 electron microscope.

\section{RESULTS AND DISCUSSION}

The isoelectric point of $N$. gonorrhoeae (Table I) reveals that, like other bacteria, they are negatively charged at physiological pH (Gittens \& James, I963). Treatment with formaldehyde increased the negative charge by blocking the free protonated amino groups (French \& Edsall, 1945), resulting in a decrease in $\mathrm{pI}$ to 4.0 . This $\mathrm{pI}$ value reflects the overall $\mathrm{pK}$ of the carboxyl groups on the cell surface and shows that acidic phosphate groups, like those present on lipopolysaccharides, do not make a significant contribution to the surface charge for, if they were present, the pI value of the formaldehyde-treated cells would be less than 3.0 (Sherbet \& Lakshmi, 1973). Treatment with EDC and methylamine blocks free carboxyl groups (Hoare \& Koshland, 1967) causing a reversal of the original surface charge and an increase in the $\mathrm{pI}$ value to $8 \cdot 2$. When both groups were blocked, the bacteria failed to migrate in the electric field confirming that these groups, presumably located in the surface protein, make the major contribution to the surface charge. The pI values we obtained with $N$. gonorrhoeae are strikingly similar to those obtained by Sherbet \& Lakshmi (1973) for Escherichia coli.

By monitoring the net surface charge on the bacterial surface using cationized ferritin, which reveals acid groups as electron-dense regions (Danon et al., 1972), we confirmed the charge revealed by isoelectric focusing. Ferritin coating was heavy on normal bacteria and 
Table I. Effect of modification of surface charge on the attachment of N. gonorrhoeae P9 to WISH cells

$\begin{array}{lcc} & \text { Mean no. of bacteria } \\ \text { Modification } & \text { attached/cell } & \text { pI } \\ \text { Unmodified } & 14 \cdot 5 & 5 \cdot 3 \\ \text { Non-pilated mutant } & 4 \cdot 7 & 5 \cdot 6 \\ \text { Carboxyl groups blocked } & 27 \cdot 6 & 8 \cdot 2 \\ \text { Amino groups blacked } & 2 \cdot 6 & 4 \cdot 0 \\ \text { Amino and carboxyl groups blocked } & 35 \cdot 0 & * \\ & & \end{array}$

Table 2. The influence of pili on attachment of $N$. gonorrhoeae $\mathrm{F} 62$ to WISH cells

Mean no. of bacteria attached/cell

Modification
Unmodified
Carboxyl groups blocked
Amino and carboxyl groups blocked

$\begin{array}{cc}\text { Pilated (TI) } & \text { Non-pilated (T4) } \\ 3 \mathrm{I} & 9 \\ 67 & 80 \\ 72 & 79\end{array}$

on those with blocked amino groups, but was scanty or absent on those with blocked carboxyl groups.

The negative charge on the surface of normal $N$. gonorrhoeae must cause an electrostatic barrier to their attachment to the negatively charged surface of human cells. Thus an alteration in the surface charge is accompanied by a change in the ability of the organisms to attach to human cells (Table $\mathrm{I}$ ). As expected, attachment is decreased when the negative charge is increased, and is increased when the bacterial surface becomes positively charged and there is no longer an initial repulsive force between the bacterium and host cell. However, despite the electrostatic barrier, attachment of normal $N$. gonorrhoeae does occur, the initial repulsive force being overcome by the attractive forces operating when the cell surfaces approach closer than a critical separation (Curtiss, 1973).

Pilation is an important factor in the attachment of normal $N$. gonorrhoeae to human cells (Swanson, 1973, 1975). However, our results show that neither in organisms with blocked carboxyl groups (positively charged) nor in those with blocked carboxyl and amino groups (electrostatically neutral) does pilation confer any advantage (Table 2). We suggest therefore that the importance of pili in virulence is to overcome the electrostatic barrier to attachment. The mechanism by which pili overcome this barrier and establish contact with human cells is not known. One possibility is that the negative charge on pili is less than that on the bacterial surface and hence they are better able to overcome the electrostatic barrier. However, this is apparently not so, for neither isoelectric focusing (Table I) nor treatment with cationized ferritin revealed any significant difference between the charge on pili and that on the bacterial surface. Moreover, we have isolated and purified pili from strain P9 and shown by isoelectric focusing that they have a negative surface charge similar to that of the bacterial surface (Robertson, Ward \& Watt, unpublished). Another possibility is that the initial contact is made by the pilus tip either because it has a different chemical composition or because its small surface area renders it less sensitive to the electrostatic barrier.

Primary attachment by a pilus would ensure that initially the two surfaces had a maximum 
separation equal to the length of a pilus, 2 to $6 \mu \mathrm{m}$ (Ward, unpublished results) and so would increase the probability of a closer approach. A close approach favours attachment as the attractive forces produced by hydrophobic interaction or London dispersion forces act over a shorter range than the electrostatic repulsive force, leading to a stable adhesion at a critical separation where the potential energy is at a secondary minimum (Curtiss, 1973). Studies on $N$. gonorrhoeae attached to the human urethral epithelium in vivo support this view as the two surfaces are separated by approximately $13 \mathrm{~nm}$ (Ward et al., I975), a distance which is consistent with a secondary minimum situation (Curtiss, 1973). This final attachment involves direct interaction of the surfaces of the bacterium and host cell and occurs to a limited extent when the bacterial cell is non-pilated. The component of the bacterial surface involved in this interaction is not known. It could well be a specific macromolecule as is found, for the particular epithelium involved, with lipoprotein and Mycoplasma pneumoniae (Sobeslavsky, Prescott \& Channock, 1968) and with M protein and Streptococcus pyogenes (Ellen \& Gibbons, 1974) in man, with carbohydrates and lactobacilli in the chicken (Fuller, 1975), and with K88 antigen and $E$. coli in the pig (James \& Rutter, 1972). If a specific macromolecule does exist then it cannot be associated with charged groups in the surface protein, for blocking of both the amino and carboxyl groups increases attachment. Alternatively attachment may simply be a non-specific interaction between the two surfaces in contact. Whatever the ultimate mechanism of attachment, the influence of pili in overcoming the electrostatic barrier is likely to be a significant factor in the pathogenesis of gonorrhoea.

This work was supported by a Medical Research Council Programme grant.

\section{REFERENCES}

Curtiss, A. S. G. (1973). Cell adhesion. In Progress in Biophysics and Molecular Biology, pp. 317-386. Edited by J. A. V. Butler and D. Nobel. Oxford: Pergamon Press.

Danon, D., Goldstein, L., Marikovsky, Y. \& SkUtelsky, E. (I972). Use of cationized ferritin as a label of negative charges on cell surfaces. Journal of Ultrastructure Research 38, 500-510.

Ellen, R. P. \& GibBons, R. J. (1974). Parameters affecting the adherence and tissue tropisms of Streptococcus pyogenes. Infection and Immunity $9,85-9 \mathrm{I}$.

FrenCH, D. \& EDSALL, J. T. (1945). The reaction of formaldehyde with amino acids and proteins. In Advances in Protein Chemistry, vol. II, pp. 277-335. Edited by M. L. Anson and J. T. Edsall. New York: Academic Press.

FULLER, R. (1975). Nature of the determinant responsible for the adhesion of lactobacilli to chicken crop epithelial cells. Journal of General Microbiology 87, 245-250.

GitTens, G. J. \& JAMES, A. M. (I963). Some physical investigations of the behaviour of bacterial surfaces. VI. Chemical modification of surface components. Biochimica et biophysica acta 66, 237-249.

HoARE, D. G. \& KoshLAND, D. E. (1967). A method for the quantitative modification and estimation of carboxylic acid groups in proteins. Journal of Biological Chemistry 242, 2447-2453.

JAMES, G. W. \& RUTTER, J. M. (1972). Role of the K88 antigen in the pathogenesis of neonatal diarrhoea caused by Escherichia coli in piglets. Infection and Immunity 6, 91 8-927.

James-Holmquest, A. N., Swanson, J., Buchanan, T. M., Wendle, R. D. \& Williams, R. P. (1974). Differential attachment by pilated and non-pilated Neisseria gonorrhoeae to human sperm. Infection and Immunity 9, 897-902.

Kellogg, D. S., Peacock, W. L., Deacon, W. E., Brown, L. \& Pjrkle, C. L. (1963). Neisseria gonorrhoeae. I. Virulence genetically linked to the clonal variation. Journal of Bacteriology 85, I $274-1279$.

Sherbet, G. V. \& LAKShMi, M. S. (1973). Characterisation of Escherichia coli cell surface by isoelectric equilibrium analysis. Biochimica et biophysica acta 298, 50-58.

Sobeslavsky, O., Prescott, B. \& Channock, R. M. (I968). Absorption of Mycoplasma pneumoniae to neuraminic acid receptors of various cells and possible role in virulence. Journal of Bacteriology 96 , 695-705.

Swanson, J. (1973). Studies on gonococcus infection. IV. Pili: their role in attachment of gonococci to tissue culture cells. Journal of Experimental Medicine 137, 57 I-589. 
SWANSON, J. (1975). Role of pili in interactions between Neisseria gonorrhoeae and eukaryotic cells in vitro. In Microbiology-1975, pp. 124-126. Edited by D. Schlessinger. Washington: American Society for Microbiology.

Swanson, J., Kraus, S. J. \& Gotschlich, E. C. (197I). Studies on gonococcus infection. I. Pili and zones of adhesion: their relation to gonococcal growth patterns. Journal of Experimental Medicine 137, $57 \mathrm{I}-589$.

WARD, M. E., Robertson, J. N., Englefield, P. M. \& WATt, P. J. (I975). Gonococcal infection: invasion of the mucosal surfaces of the genital tract. In Microbiology-1975, pp. 188-199. Edited by D. Schlessinger. Washington: American Society for Microbiology.

WARD, M. E. \& WATT, P. J. (1972). Adherence of Neisseria gonorrhoeae to urethral mucosal cells: an electronmicroscopic study of human gonorrhoea. Journal of Infectious Diseases 126, 60I-605.

WHITE, L. A. \& KELLOGG, D. S. (1965). Neisseria gonorrhoeae identification in direct smears by a fluorescent antibody-counterstain method. Applied Microbiology 13, I 7 I-1 74. 